\title{
Discussion of General English and Academic English in College English Teaching
}

\section{Luo Yafeng}

Weinan Normal University, School of Foreign Studies, Weinan, Shaanxi, 714000

\author{
Keywords: College English, General English, Academic English, Development Direction
}

\begin{abstract}
With the continuous acceleration of the process of economic globalization in China, the international cultural exchange has gradually increased. English has become an important part of our daily work and communication. With the further reform of education and the improvement of English teaching quality, College English teaching must reposition itself. There are some differences in purpose between academic English and general English. Academic English is based on professional needs, focusing on the cultivation of students' professional learning ability. In today's economic globalization and educational internationalization, in order to meet the needs of international construction, colleges and universities need to transform their traditional teaching aims and cultivate their academic abilities in English research. The organic collection of academic and general English will promote the development of College English teaching. Although there will be irresistible resistance in the process of development, it is still the direction of the development of English Teaching in universities and colleges in our country.
\end{abstract}

\section{Introduction}

The "guide to college English Teaching" in the edition of the Ministry of education is the first time to incorporate academic English into the content of College English teaching. In 2013, the Shanghai College of Education promulgated the "reference framework for College English Teaching (Trial)", which stipulates that "general academic English curriculum should be set up as a required character". It is recommended that freshmen learn English as a required course [1]. These Provisions aroused great controversy in the field of foreign language, the main point of view is divided into three categories: one is the dominant position to occupy the academic English in College English, the edge will cause the general English; second think English is dominant, academic English can only develop in a part of the University, such as 985 or 211 colleges; the third is a compromise position, that the two can coexist complementary [2-3]. This is an argument between common English and scientific and Technological English, which is of great practical significance to the teaching orientation and future development of College English in China.

\section{General English and Academic English}

General English is first introduced by Hutchinson and Waters, and they are divided into two categories: specific purpose English (ESP) and general purpose English (GE). The specialized use of English is derived from English for Academic Purposes (EAP) and English for Occupational Purposes (EOP) two categories according to different purposes. From the perspective of historical development, ESP is dominated by academic English and continues to occupy a dominant position in the world [4]. General English is relative to professional English, which is only for college students to learn English subjects in college life. Its main purpose is to help us communicate better, rather than point to a specific specialty / discipline / occupation. Academic English is very pertinent, which is set up to meet the specific needs of the learners. The teaching aims between the two are different. General English is the purpose of the examination, in addition to language learning without any purpose, so general English is also called basic English.

Learning English is an important part of higher education, which is in the process of English teaching, targeted for individual study, its main purpose is to help students to use flexible in the 
future work and professional direction, clear objectives and direction. Therefore, it should train students to listen to lectures, take notes and read professional documents in English, write academic papers or academic articles in English, and participate in academic discussions in English. In addition, but also cultivate their academic accomplishment, can independent learning and research network is a skilled application of library resources; on the various channels to collect information with analysis and comprehensive ability; ability to comply with academic norms; and excellent communication skills with team [5]. In the new era of academic English training, talents need critical thinking, communication, teamwork, creativity and cross-cultural communication skills. The object of teaching is very common, not only including masters/doctoral graduate students, but also undergraduate students in general and even higher vocational college students.

\section{The Instrumentality of Academic English and the Education of Humanistic Quality}

\subsection{The instrumentality of academic English}

In the 2007 place, the requirement of College English curriculum is positioned as "College English is not only a basic knowledge course of language, but also a quality education curriculum for broadening and understanding world culture". This position is generally applicable to general English and academic English. For non-professional students, College English is a tool. Its main value is to help students master the ability to read and communicate professional information in English [6]. In twentieth Century, our country was in a closed state, and learning English as a specialized language knowledge, its main purpose is to improve self-cultivation, highlight the humanity of English, and limit its instrumentality. But in the twenty-first Century, with the coming of economic globalization and the era of educational internationalization, English is the universal language of scientific research achievements in the world, and its instrumental characteristics are more obvious, which meets the needs of the state's ability to communicate with other countries. As a language service unit, College English has a clear demand for services [7]. Colleges and universities are also actively introducing foreign excellent teaching materials and teaching teams, vigorously cultivating professionals with international communication skills, and paying more attention to the principles of College English.

\subsection{Academic English and humanistic quality education}

The instrumentality and humanism of language are an organic whole and inseparable. Therefore, it is not correct to classify academic English into tool class and classify general English into the humanities class. It is a lack of a comprehensive understanding of academic English and general English. To analyze the subject through the publication of the Shanghai Jiaotong University and Pearson Education of academic English design to many fields of society, including cultural and intercultural communication. The main purpose is to broaden the students' international vision and improve their comprehensive quality. College English textbooks usually have corresponding humanistic nature, while academic English adopts the cultivation of critical thinking ability and scientific methods, pays attention to the humanities quality and scientific literacy education, and trains college students' ability of collecting, analyzing and comprehensive utilization of resources and literature [8]. Academic English has a higher demand for the basic quality of today's college students. They can use English to carry out academic discussions, report scientific research achievements, and analyze and solve problems independently.

\section{A New College English Teaching Coexisting with General English and Academic English}

\subsection{Changing the traditional teaching idea and perfecting the curriculum system}

The so-called reform of the traditional teaching concept, perfect college English teaching system. At the same time, colleges and universities can set up two series of courses in general English and academic English, enriching the content of the class and showing the characteristics of the class. For example, the general plate has different courses of choice on the school's own situation, such as 
expression class, speech class, debate class, writing class, etc. There are also practical courses, such as making English video clips, writing English newspapers, etc. To make corresponding credits, only to complete the required credits can we graduate. As for the choice of general English or academic English, students can choose themselves according to their own conditions and teachers.

\subsection{Both instrumental and humanistic goals}

The new college English teaching system divides the goals of the curriculum into two categories: first, the general purpose of College English; second, the classification of general English and special English. The purpose of the College English teaching system is that English as a tool of language can not be replaced. In addition, College English also has the humanistic goals shared by the general curriculum, improving discrimination ability, developing learning ability and improving comprehensive quality, etc., which requires college English to cooperate with other courses together. Therefore, in the process of College English teaching, we should give consideration to both instrumentality and humanity [9]. If we emphasize instrumental nature, we will lose the value of educating people. On the contrary, we cannot emphasize the value of English curriculum, and also reduce the value of English curriculum. Although the two are equally important, but in the actual teaching process, it is not to divide the class time. Humanity is mainly reflected in the selection of textbooks. When selecting textbooks, we should give full consideration to students' cognition, emotion and morality, enrich the contents of textbooks, and diversify teaching contents. It does not require extra classroom time, and requires teachers to infiltrate into daily teaching activities when the explanation of knowledge is carried out.

\subsection{Adopting a diversified teaching model}

With the development of economic globalization and education internationalization, all walks of life have new requirements for the quality of English Teaching in Colleges and universities. Colleges and universities also carry out many reforms in College English. According to the different training objectives of different departments, we adopt a diversified teaching mode to plan the future development of students reasonably. First, we can reasonably divide the length and period of College English teaching according to the freshmen's English level and goals, and provide students with different selection models and differentiated management [10]. Teachers can also draw more time and energy, set up different types of curriculum strengthening to improve the students' English learning level. For example, the English summer camp held by Tsinghua University has created a good English learning environment for students and effectively promoted the use of English communication. On the other hand, we should provide elite teaching for high level students, adopt academic English teaching methods, protect their enthusiasm for learning English, and integrate English teaching into practical communication.

\subsection{General English focuses on cultural communication, academic English and academic communication}

The general English series focuses on cultivating students' cross-cultural communicative competence, and setting up corresponding courses around Chinese externalization. The course content can also be carried out from the historical and hot topics, focusing on the national conditions, the political system, hot events and so on. The Chinese and foreign political and economic systems are compared, and the way of life and time in foreign countries are analyzed. The topic of historical comparison between China and foreign countries is also more extensive, such as historical culture, traditional festivals and so on [11]. Through the study of these courses, it helps the students to understand the cultural differences between the West and our country correctly, so as to improve the learning effect of general English. The teaching of academic English is mainly undertaken by professional English teachers. It provides students with 3 kinds of academic skills, 4 academic literacies and 5C abilities for students to complete English courses. 5C refers to critical thinking skills, communication skills, collaboration skills, creativity ability and cross-cultural competenceintercultural skills. 


\subsection{A teaching method combining theory with practice}

There has been a separation between theory and practice in China's education, which is influenced by the curriculum planning in the traditional teaching methods. In the course of teaching, language is explained, and the cultural and structural arrangements behind the language are selectively ignored. Therefore, in the process of teaching, teachers should infiltrate the central idea of the text into the teaching process, so that students can fully understand the word grammar and the implied meaning of the article. When Qiufang put forward the "science synthesis" 2013 teaching philosophy, emphasizing the combination of theory and practice. Its core idea is: learning English as a normal life, constantly learning new knowledge, learning and using, realizing the perfect combination of theory and practice. The key to realize the teaching method in College English teachers, so teachers should design a task with value of students' language proficiency, and provide relevant learning materials for the teachers to participate in the mission; to actively guide students to complete the task, and the performance of the students to carry out targeted evaluation. It subverts the traditional teaching idea and uses the content they have learned as the teaching purpose, and improves the teaching achievement and the comprehensive accomplishment of the students.

\section{Conclusion}

To sum up, from the first English syllabus that appeared in 1980, to the end, the teaching of College English has been over thirty years. Especially in the twenty-first Century, the economic globalization and the development of education internationalization, the society has put forward new requirements for College English teaching. General English and English for academic debate has never stopped, so we need a full understanding of the two languages, English and academic English distinguish the differences of general existence and continuity, change the teaching mode and the traditional concept of the organic combination of the two. In order to improve the teaching efficiency and study results, we should build a diversified curriculum plan and choose the suitable learning model according to the students' own situation.

\section{References}

[1] Mao F J, University C M. From the General English to College English Teaching Reform,The Transformation of the Academic English Study[J]. Education Teaching Forum, 2017.

[2] Huang W. An Alternative of Transition between College English Teaching and Bilingual Teaching_-General Academic English Course[J]. Journal of Qinzhou University, 2017.

[3] Hong M, Jianqiang L. How Chinese Exchange Students Adapt to Their Academic Course Learningin a US University: A Fresh Look at College English Teaching in China[J]. Cross Cultural Communication, 2013, 9.

[4] Qian Y, Wang T. Research on the Progressive Teaching Contents of College Academic English Writing[J]. Education Teaching Forum, 2017.

[5] Xi Q I. "Academic English" curriculum construction at the transitional stage from EGP to EAP in college English teaching[J]. Foreign Language World, 2015.

[6] Cai J. Brand new teaching philosophy and methodology: a study of English for academic purposes and College English[J]. Foreign Language Learning Theory \& Practice, 2014.

[7] Shi J. How to arouse the learning interest of students with poor academic performance in college English teaching [J]. Journal of Jiamusi Vocational Institute, 2017.

[8] Gong S, Zhang Y, Jiyue H U. English Forum on Medical Humanities of SMMU: An interdisciplinary innovative teaching practice[J]. Journal of Medical Colleges of Pla, 2013, 28(1):4-10.

[9] Zhang H Q, Department B. Research and Construction of College English Curriculum Module in Private Higher Colleges[J]. Journal of Hubei Correspondence University, 2017.

[10] Kojour M K, Heirati J K. Teacher's and Students' Beliefs on English for General Academic Purposes: The Case of Iranian University Students[J]. English Language Teaching, 2015, 8(12):37.

[11] Tang Y. A Contrastive Analysis of Chinese College English Syllabus Word List with a General Service List of English Words and Academic Word List[J]. Studies in Literature \& Language, 2014, 8(1):66-70. 